\title{
JOURNALISM OF NORTHWEST IOWA ${ }^{1}$
}

\author{
By Hon. Charles Aldrich
}

Mr. Chairman, Members of the Editorial Association, Ladies and Gentlemen:

It really seems to me that I should make you an apology for presuming to address you upon this occasion, much as I feel obliged to you for the kind invitation with which you have honored me. As I understand this invitation, you expect me to say something of my experiences in the early journalism of northwestern Iowa. My time has been so constantly occupied by other cares and duties as to render it a matter of great difficulty to make even the most hurried preparation. I could not, however, very well decline, for of the few journalists who came to this region about the time I did-almost thirty-four years ago-I believe no other is now living.

In addition to learning my trade as a practical printer, I had had about five years experience as the editor and publisher of a country paper in the towns of Randolph and Olean, in Cattaraugus County, New York. But I sold out and spent a year on my farm, by which time I was overcome by a most decided longing to get back into the atmosphere of a printing office. Some of you may know how this is yourselves. Having had some acquaintance with Horace Greeley, I consulted him in regard to coming this way. He wrote me very kindly, giving me the same good advice which he had written or spoken to so many thousands of others"Go west, young man!" I have ever regarded that letter as one of my most precious literary belongings. It is now in the Masonic Library at Cedar Rapids. I had procured a little book by N. H. Parker, relating to the state of Iowa, in which he paid a most glowing tribute to the valley of the Upper Des Moines, incidentally mentioning Webster City and Fort Dodge. I had also read in David Dale Owen's Geological Survey of Iowa and Minnesota that great scientist's opinion that the country radiat-

${ }^{1}$ This address was delivered by Hon. Charles Aldrich at a meeting of the Upper Des Moines Editorial Association, held at Webster City, September 12, 1890.Editor, 


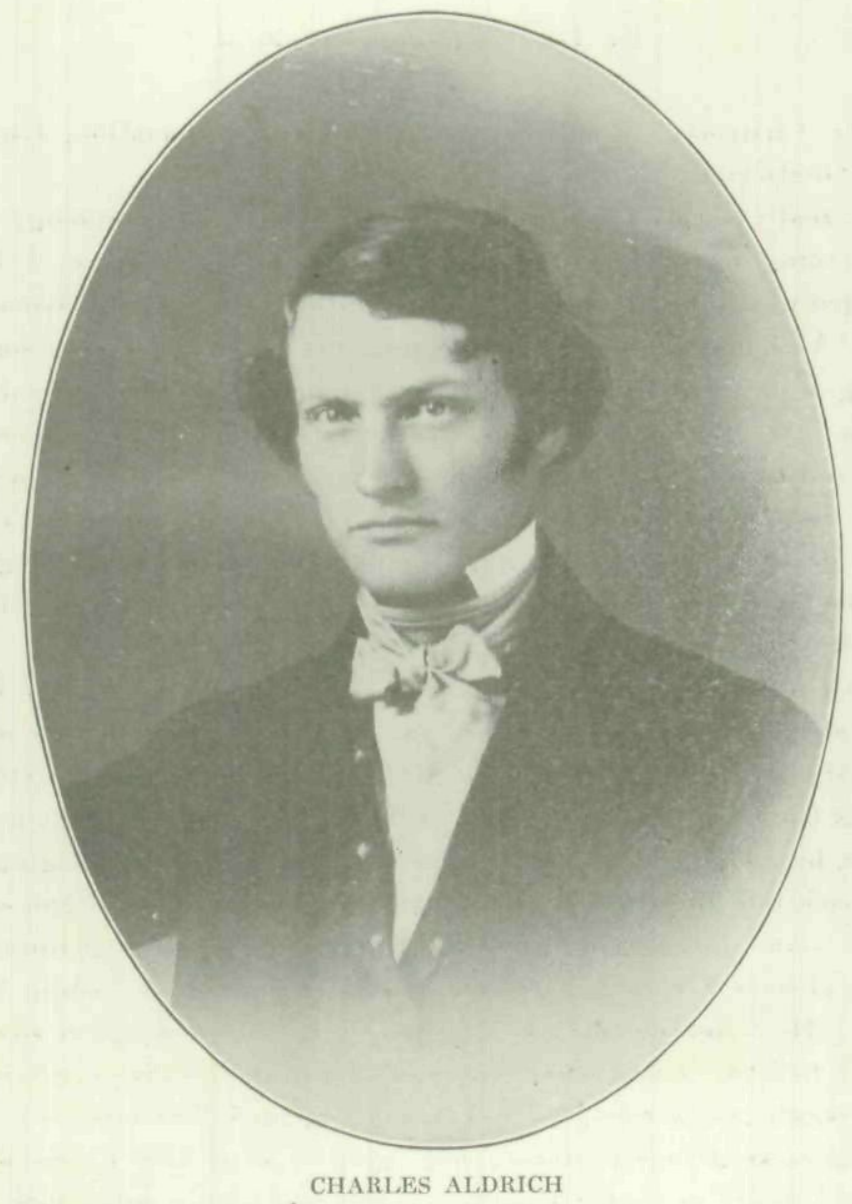

(From a daguerreotype of 1851.) 
ing in all directions for at least sixty miles from Fort Dodge was "one of the most fertile upland plains in America." That is a pretty good opinion to quote, even at this late day, and we all know how true it is. * * * I therefore thought it would be a good region to settle in. So I started for Iowa early in February, 1857, intending to go as far west as Fort Dodge, thence south to Des Moines, and from there home. I hoped to find a location somewhere, but had built my hopes largely upon Fort Dodge. In Dubuque, however, I met Colonel J. B. Dorr, of the old Express and Herald, who somewhat upset my calculations by informing me that a paper had just been started or was soon to appear at Fort Dodge; but he stated that Webster City was a new county seat, a smart place, and wanted a paper. I therefore determined to push right along. There was no railroad west of Dubuque. True a track had been laid out thirty miles to Dyersville just in time to save the first quota of the land grant, but it was buried in some places ten feet deep by the snows of that terribly severe winter. We started long before daylight from the comfortable old Julian House, on one of the zero mornings, in an open sleigh run by the Western Stage Company. We had a jolly load of passengers, a good time generally, and were two days reaching Cedar Falls. West of that town travel was simply impracticable. The snow had been very deep all winter, and just now a thaw had partly melted it. There had been extreme weather of all imaginable varieties. The water had spread over thousands of acres, and was not yet frozen hard enough to bear a horse. I was compelled to stay a whole week at Cedar Falls, relieving the homesick monotony of the long delay by setting type and doing some writing in the office of The Gasette, published by a couple of young men whose names I can not now recall. At last, after one very cold night, the stage company decided to send out a team with the letter mail and myself, the sole passenger. Our carriage was a rude pung, or jumper, a sort of improvised sleigh or cutter, of which you may now and then see a sample in frontier places. The roads were fairly good and we reached Iowa Falls, a smart little town of 100 people, about 9 o'clock on a dark and very cold evening. We passed over the sites of the flourishing towns of Parkersburg, Aplington, and Ackley, upon neither of which was there yet a 
single settler. In crossing one of the deep creeks, as a matter of precaution, fearing the ice might give way, the driver took the horses over singly, and I held them on the farther side while he drew over the light pung by hand. I remember that in the bright moonlight the ice looked very thin, and that a fierce north wind was howling over the prairies. A cold bath out there might have interfered with the appearance of the Hamilton Freeman. Our journey of nearly fifty miles was made without changing horses, where ordinarily there were three or four changes. It was too cold to bother about changing horses.

Early the next morning we started in a big farm sleigh for Webster City. The weather was much colder and the air filled with frost and snow. In fact it lacked little of being a veritable blizzard. At noon we reached "Skunk Grove," fifteen miles south of east of Webster City. It is now known as "Rose Grove."

But what's in a name? That which we call a rose,

By any other name would smell as sweet.

Mr. William Cheney had settled there, and was keeping a snug and most comfortable hotel-doubly comfortable from the Arctic condition out of doors. We were ushered into a pleasant room with a blazing fire, and in a few moments Mrs. Cheney handed each of us a glass of hot whisky, which was peculiarly vivifying in our benumbed, half-frozen condition. I have distinct recollections of a most excellent dinner, and of a pretty, red-cheeked, black-eyed girl, in a blue cashmere dress, who played the piano and sang several beautiful songs. Really I think you will believe me when I declare that that house was a genuine oasis in a winter desert. But good $\mathrm{Mr}$. Cheney died many years ago, that pleasant, pretty girl is herself a grandmother, and her young brother is a portly, gray-haired banker and substantial citizen of Fort Dodge.

We resumed our journey in a blinding snowstorm, reaching Webster City long after dark, wearied and well-nigh frozen. The driver left me at the hotel kept by Ammon Moon on the eastern margin of our town plat, whence the business of the city all retreated twenty-five years ago. The hotel was very good for that time in our history, but I remember that I slept on a hard bed of prairie hay, and could only keep warm by wrapping myself in my shawl and overcoat. When I looked out the next 
morning on the little hamlet of less than 200 people, and the wide waste of snow by which it was surrounded, it occurred to me that I had come to a sorry place to start a newspaper. The times were very hard and almost everybody was poor. Money readily commanded forty per cent interest. The winter, as I have stated, had been one of unusual severity, and travel had almost entirely ceased. There was no sale for town lots or lands and stagnation had set its seal upon everything. But the town and Fort Dodge had just been made county seats by an act of the legislature, and I believed that any county seat was a good place for a paper. One could simply bide his time and "grow up with the country." It was but a few hours until everybody knew me and the errand that had brought me there from the state of New York. I looked the situation over as thoroughly as possible, and made my arrangements to come with a small printing office and start the Hamilton Freeman. The citizens were to pay me a bonus of $\$ 500$ and they guaranteed me 500 subscribers. I stipulated to continue the paper one year. The bonus came promptly as agreed, for the contract bore the names of W. C. Willson and Jacob M. Funk, still enterprising residents of that town, and was as good as an acceted check on one of our present banks. The subscribers came at last but slower. It was usual in starting papers in these new places to require some such help to make up for the legitimate business which only came after the greater development of the country. In fact few of the pioneer publishers could have budged an inch without such aid. I make this statement most cheerfully, for I desire that all who aided me in any way in founding the Freeman shall have the fullest eredit.

This business settled, I left for my eastern home with a teamster bound for Iowa City. Dining again at Skunk Grove, we struck out over the twenty-five-mile prairie between that point and the nearest house in Hardin County, reaching the residence of a settler named Dilsey late at night. This was a favorite stopping place for travelers, though the little house was only about fourteen or sixteen feet square, with an attic under the low rooftwo rooms, one upstairs and one downstairs. But it was all very comfortable, for Mrs. Dilsey was an excellent cook, and teamsters always found good quarters for their animals. The next 
morning, instead of being able to resume our journey, we were in the midst of the most terrible blizzard I have ever seen. The winds shrieked and howled, and the air was so full of snow that one could scarcely see a rod. Added to all this it was most intensely cold. There were thirteen people in the little log house, and when night came some slept upon beds made upon the floor, while others elimbed the ladder and lodged in the attic. We were really packed together like herrings in a box. It was not until the third morning that the storm had ceased. The sun then rose clear and bright, and we were off again in good season. We reached Iowa City, where the last legislature held in that old capital was in session, some days later, without any special incident. The railroad was open from that point east and I was not long in reaching my old home.

Some days later I visited New York City, purchasing of James Connor, the venerable type-founder, who has long been gathered to his fathers, the little outfit for my paper. I selected long primer type for the reading matter because it was quite large, and as I expected to set most of the type myself, I could not afford to use anything smaller. The advertising type was nonpareil. A new number three Washington hand press, and a limited assortment of job type, completed the outfit. The whole cost $\$ 700$, and was paid for, probably for the reason that a printer going out to far Iowa to start a paper would have found it an utter impossibility to get credit. This freight was shipped to Dubuque, via Lake Erie, where it arrived early in May. I was there some days ahead of it, and while awaiting its arrival engaged as a compositor on the old Dubuque Tribune, published by A. W. Hackley, earning enough to pay our daily expenses. Hackley was an able editor in some respects, but had a curious way of using semicolons, sometimes sprinkling five or six of them through a sentence where none were needed. The poor old man failed in business and died twenty-five years ago in extreme poverty. Hon. C. T. Fenton, one of my earliest and best friends, who died last February, met me at Dyersville with a team to bring part of my freight, and a horse and buggy for my wife and sister. We brought the type, cases and stands, so that I could set up the first number, while a six-ox team went back for the press. It was many days before the press came, and 
when it did the paper was all set up, and largely by my own hand. In those days and for years afterward I rarely wrote out an article, but simply took my stick and rule and composed it as I put it in type.

The little paper was well received by the few people thereabouts, and its circulation began to grow at once. It was most cordially welcomed by the press of the state. In my second number I had the good or bad luck to criticise, in pointed, but in legitimate and truthful language, certain acts of a man in high public position. I wrote what I intended merely as a paragraph of general political news-perfectly legitimate and proper, as I view the matter today. But I stirred up a hornet's nest of monumental proportions. The Freeman was widely assailed and its editor not only severely denounced, but even threatened with personal violence. Several of the leading papers of the state, however, promptly sustained me, for I was plainly in the right. The consequence was, and I think I may say it without egotism, that before the Hamilton Freeman was six weeks old it had a name and a reputation throughout the state. Its polities, when we had such stupendous issues involving the greatest of moral questions as led to the War of the Rebellion, was radically Republican. I was one of the few north Iowa editors who heartily supported Governor Grimes, one of the giants of those days, for the United States Senate. He thanked me for this in a very pleasant letter which you can see in the Iowa State Library, making most kindly mention also of Cyrus C. Carpenter, a young man whom we sent to the legislature of 1858, the first ever held in Des Moines.

When I issued the first number of The Freeman, the Fort Dodge Sentinel had been running a few weeks as a Democratic organ, edited and published by A. S. White. The Boone County News by Luther C. Sanders, and the Eldora Sentinel by James Spears, began to be published about the same time. The two last named were Republicans. They were all good printers, editors whose papers were always able and spirited, and genial, pleasant gentlemen. White was the finest printer and the best business 
man. Sanders was a fair editor generally, and I think our state has never had a keener paragraphist:

$\mathrm{He}$ was one whose wit

Without wounding could hit,

And green be the turf that's above him.

Spears had a more decided turn for politics, and his ability was widely recognized throughout the state. When John Scott was nominated for state senator at Nevada in 1859 Spears went nearly wild with enthusiasm. I think the nimble fellow must have jumped up more than four feet from the floor of the old court house. White and I used to have splendid times excepting when elections were close at hand. Then you may imagine that things waxed warm. The Democracy had had things its own way a long time and relaxed its grip upon the spoils with great reluctance. The campaign of 1860 had been one of most unusual bitterness. White and I had not recognized each other for some time previous to February, 1861, when we both started for Washington to attend the first inauguration of Abraham Lincoln. When the stage came in from Fort Dodge only one seat was left for me, and that was by the side of White. "G'morning," said he. "Morning," said I. We rode several miles before either spoke again. Gradually, however, toward night we both thawed out a little, but bore ourselves toward each other with great dignity. The second night we stopped twenty miles this side of Cedar Falls where we had to sleep together, illustrating in a new sense the old adage that "politics makes strange bedfellows." Here we were snow-bound in a small $\log$ house, remaining two or three days until the fierce blizzard subsided. By that time our animosity had completely evaporated.

But all of these, my early friends and contemporaries, are dead. They were good men and true, and each labored most zealously and unselfishly in the work of advancing the interests and developing the resources of this most beautiful section of our state. White left a fine property for a country publisher of his time, but both of the others, though harder workers, died poor.

White used to go through Webster City enroute for printing office supplies with a six-ox team. On such voyages he wore a hickory shirt, slept under his wagon cover, and wielded a whip with which he could easily touch up the leaders as he sat in the 
vehicle. The journey to Dubuque and back occupied twenty days. George E. Spencer flourished in Clay and Dickinson counties in those days of speculation. The first time I saw him was while he was passing through here with just such an outfit. After the war he was for twelve years a carpetbag United States senator from Alabama.

The election for representative in the legislature in the autumn of 1857 was a red hot one. Cyrus C. Carpenter and John F. Duncombe, both of Fort Dodge, were the candidates. If my recollection is correct the district included nineteen counties. The vote was very close, requiring the official canvass to determine the result. Carpenter had about 125 majority. Duncombe had a very strong hold upon the Republicans of our town, through some railroad issue, and got a large majority in spite of all we could do. But we had a "Carpenter Festival" to celebrate our victory. After the supper Carpenter made a rousing speech, promising to do all in his power to locate an insane asylum here for the special custody. of the Republicans who had been so led away from their own fold. And the Republican boys!-whythey

Danced all night,

Till broad daylight,

And went home with the girls in the morning.

After the financial crisis of 1857 times became very hardharder than most of you can imagine today. Gold and silver, which were plenty when I came in the spring, disappeared from circulation, and were replaced by the paper of speculative, wildcat banks, said to be located in Nebraska. It was called "reddog" currency, and the banks were so constantly bursting up that when a man got one of the bills he didn't dare to keep it until the arrival of the next mail for fear of its becoming worthless on his hands. While this state of things lasted I paid my paper bills with unusual promptness, for having no banks, we were in the habit of remitting currency or buying drafts which had been sent in to the county treasury to pay taxes.

Potatoes were worth $\$ 3.50$ per bushel when I arrived back in May. That autumn they went begging at ten cents per bushel. I saw wheat sold in Webster City for twenty cents per bushel, and much better wheat than our soil produces at this time. Corn 
was often a drug at ten cents. In fact, during the days of tencent corn, it was burned for fuel, and was actually cheaper for this purpose than either coal or wood. I saw people twisting prairie hay into knots and burning it for fuel. The season of 1858 was very wet. There was a succession of thunder storms and heavy rains all summer and an early frost in the autumn. The corn was soft and worthless, and good hay as scarce the following winter as good tea or coffee at the average hotel. Times grew bluer and bluer all through that year and 1859, and there was little improvement until prices were raised by the war. I used to see farmers come to town barefooted who subsequently became well-to-do and prosperous. They went barefooted because they could realize nothing from their farms. Grain stacks stood in some instances unthreshed, until they were bored through and through by rats, and utterly destroyed. Speaking of ratsthere were none here originally, but they speedily followed the settlements. They know the difference between Indians and white folks. They are evidently an adjunct of high civilization. Those were days of real pioneering-roughing it in downright earnest. People who came in from 1862 to 1875 know little of the privations and hardships of those who were here from 1854 to the dark days of 1858, '59, '60, and '61. A farmer in one of those years who had taken two copies of the Freeman wanted to pay me in wheat at twenty cents per bushel, but I told him I had rather he would owe me, for I could realize nothing from the wheat. I took it, however, and it was at last destroyed by worms, for I could not get it to a flouring mill and it was not worth hauling to the railroad.

During those very stringent years-'58, '59, and '60-I should have had hard work to keep the little paper alive but for the fact that the Republicans of many of the northern counties either came to me for their printing, or I went out and did more or less canvassing among them. Their ticket printing for the annual elections I received as a matter of course, the pay for which was always liberal. I had many subscribers up your way-a few at each county seat, and they always paid the printer. The Freeman was really the Republican organ for the counties of Webster, Humboldt, Kossuth, Clay, Dickinson, Pocahontas, Palo 
Alto, Worth, Winnebago, Cerro Gordo, Hancock, and Wright. But some of these counties contained only just people enough to build bridges and courthouses, steal the swamp lands, and grind out county bonds and county warrants, leaving the honest, abiding settlers a legacy of fraudulently incurred indebtedness. Just think of an ardent eandidate coming down here across country from Algona or Forest City to get tickets printed for an election. Possibly he might even sleep out on the tenantless prairie, coming or going. I was at the growing capital of one of these counties not long ago, where I was informed that the supply of certain blanks with a line above the rule at the top which read, "Aldrich, Printer, Webster City, Iowa," had not run out even to this day. One of two things must certainly be true- either I printed a big supply or the officers didn't use many.

These canvassing journeys were such an element of my existence, such a fountain of support to the Freeman, they were such a mystery to those who wished the paper to die out, that I will give an account of a few of them.

I spoke of the paper as having enemies. It certainly did, but they forgave me years ago, as I forgave them. Most of them are dead and forever removed from animosity, even if it had unhappily survived, which, with me, it has not.

December 2, or 3, 1859, I started for Bristol and Forest City, via Mason City. Hancock County had no shire town, but it did have a most excellent executive officer in its county judge, Hon. M. P. Rosecrans, a nephew of the distinguished major-general. A goodly share of his patronage came this way until a printing office was located nearer home. My outfit for the journey was a horse and buggy. The horse was exceedingly thin, in fact you might have counted his ribs from afar off. But our primeval liveryman, Sumler Willson, assured me that he would go as far as I wanted to ride. My companion on this trip was Sam H. Lunt of Homer, six or eight miles south of where Webster City now is. It was the shire town of Webster County in the Silurian period. He was one of the most accomplished business men I have ever known and became chief clerk of the State Land Office. The register of the land office, Captain Amos B. Miller of Mason City, whom Sam then went to see, was killed at the battle of 
Pleasant Hill, Louisana, in April, 1864; and Lunt died down south, while holding some appointment in the Commissary Department. Mr. Willson gave us a tattered old buffalo robe. I had an overcoat and shawl, while Lunt only had his ordinary coat and a blanket. But the weather was beautiful and the temperature very mild. Just a suggestion of snow lay upon the ground. We sped along finely, driving across Wall Lake on the ice, making Belmond and Mason City in good time. From the last place we went on up Lime Creek toward Bristol. But in the meantime the snow was deepening rapidly on the ground, though none was falling. The days were still bright and pleasant. We took dinner with an old farmer at the upper grove on Lime Creek, starting across for Bristol about 2 P. M. We were told that it was only a dozen miles across, and that a settler named Caswell-a name I have never forgotten-lived a little more than half way over, who would keep us if we could not get through. So we started on quite merrily, but someway the darkness seemed to fall down quite early, the snow deepened to a foot, the weather grew very much colder, and at last our horse tired out and would only go by being led. I did not blame him, for I think he did his best. Finally, at 8 P. M. he refused to budge another inch. We were on the top of a high mound or ridge and we strained our eyes to see "the light in the window" of that hardy pioneer. One can scarcely imagine how welcome a light in a log eabin can be, until he is lost on a wide prairie in a winter's night. But we had to remain right there till daylight, and we were very badly stayed with. We got no sleep, for we did not dare to sleep. When we became too cold to endure it longer we turned out and walked or ran. In the morning we found a path of ice a dozen rods long which we had made by this persistent tramping. I saw the great full moon rise and set, and I saw the sun come up out of a dreary waste of snow. As the sun rose there were millions of ice crystals on the tall prairie weeds. The settler's cabin was not visible, though we could see many miles north and east. It was evident that we had either been misdirected, or had completely lost our way. We therefore "took the back track," to the evident pleasure of our jaded horse. The old fellow had pawed away all the snow he could reach and greedily eaten the dead grass. On the way out Lunt took an overdose of some sort of 
cough medicine which made him violently ill. He insisted that I should leave him and go for help. So I left him sitting in the buggy while the old horse and the buffalo robe and myself flew off on the wings of the wind, so to speak, toward the south, in quest of help. The only help I could get was a settler who went out with an ox team and sled to bring in Sam. They did not get back to the farmhouse whence we had started the day before until 4 P. M. Sam had happily recovered from his sickness and was quite ready for a square meal.

A night or two later a wild blizzard came down from the northwest through which we could scarcely have passed alive. I hired a farmer to go with a sleigh and horses and carry me to Bristol and Forest City.

Six weeks later I returned over the same route to deliver sets of printed blanks to the several counties, but you will readily believe that I did not start with any such outfit as before. I had a sleigh and horses, with buffalo robes, bed quilts, blankets, hot blocks, provisions and forage, sufficient to camp out anywhere for a week. The late ex-Judge Daniel D. Chase, who had not been here many months, went with me. He was a dapper, handsome young fellow of twenty-six years, a trifle stiff and dignified, wearing a tall bell-erowned white hat, and a very considerable expanse of stand-up shirt collar. He hadn't succeeded in getting much business up to that time, and I told him it was because he put on too much style. I said that he must discard that downeast hat, praise the cooking wherever we stopped, and express the highest admiration for all the babies, or he never could get a case above a calf lawsuit. He seemed to profit by this advice, for I never saw a man in my life who could tend a big, fat cornfed youngster on each knee to better advantage. But he was young then and ambitious. He used freely to admit that he returned from this trip with several profitable retainers.

Our route lay northeast across the prairie from Webster City to Belmond, then the smartest town in Wright County, and thence to Mason City. We paid little attention to the roads. The weather was intensely cold, the snow quite deep. Our faces were severely frozen, and on one occasion we completely lost our way in a great swamp in Worth or Winnebago County. It was in the timber and filled with islands covered 
with brush. It was a matter of impossibility to get out, except by taking the back track, which led to a hut occupied by an old hermit who was out there holding down a homestead claim. He kindly piloted us through the labyrinth, and the weather having moderated we had no further trouble. I spoke of Judge Chase as a trifle stiff and stylish when he first came to Iowa, but I want to bear this testimony - that he was one of the best men I ever traveled with on a rough trip. He could put up with the poorest fare, and he never shirked his share either of the toils and labors of the road, or of the landlord's bills. He could always devise some means to repair a broken tug or whiffletree, get out of a bottomless slough, or kill a prairie rattlesnake.

I will speak of one other journey. I went to Spirit Lake in 1859 , the only time I was ever there. I had a superb black mare, Old Kit, true as steel, fleet as the wind, docile and kind. I am glad to say these words of the faithful animal, even though she has been dead for a quarter of a century. I went in a top buggy, following a couple of gentlemen from Fort Dodge. The road to Fort Dodge then turned south out west of town to avoid a big slough, "the Brushy." One of the Fort Dodgers was over to Webster City to see his ladylove, and was exquisitely fixed up in white pants, patent leather shoes, etc., etc. They thought they could get through "the Brushy," and I knew that Old Kit and I could certainly follow wherever they could lead. So we all went straight ahead. But alas for human hopes and expectations! Their horses both went down in the middle of the big slough, and the man with white pants and patent leather shoes had to get out and help them up, wading through mud and water four feet deep. Old Kit also went down, and I was obliged to wade out, too. These sloughs were no respecters of persons. Speaking of prairie sloughs, however, I am forcibly reminded that as a consequence of their having dried up, an important element has dropped out of our political electioneering nomenclature, though you may still have it up in Dickinson and Emmet counties. Candidates were eternally boasting of their unparalleled prowess, sacrifices, and exposures in wading sloughs. I told one of them through the Freeman that I believed a pillar of granite with a Latin inscription would some time be set up on each side of the sloughs he had waded, as they show to this day where Hanni- 
bal crossed the Alps, and Washington the Delaware. But the prairie slough is almost wholly a thing of the past and the irrepressible candidate can cross them dry-shod. In these latter days the wire fence seems to be the only source of irritation. At Fort Dodge I fell in with Cyrus C. Carpenter, who has since been the recipient of so many public honors, and whom you all know so well. He accepted my invitation to go along. We had a good time, on the whole, though we were nearly eaten up by mosquitos, and one day was so hot that we were unable to travel. At our noonday halt half way across the wide unsettled prairie between the west fork of the Des Moines River and Spirit Lake, we were nearly famished for water. Carpenter descried a bunch of "black grass" almost a mile away, for which he started to get some water, which, from his experience as a surveyor, he knew to be there. After a long time he returned with a couple of quarts in our horse bucket-a decoction of decayed grass and rushes-but it was wet, and I thought I never had a drink more refreshing. Spirit Lake was then a little village of perhaps 100 people. Estherville, which now furnishes the Republicans with their eloquent candidate for secretary of state, was occupied by but a single settler. We fished and swam in the lake, which has since become so famous as a watering place. I think that Spirit Lake then surpassed in beauty any sheet of water I have ever seen. I need not speak of the orders I received on this trip. It may be presumed that that element of the expedition was not neglected.

It was four or five years after I settled here before the railroad reached Cedar Falls. We had to haul all our supplies 150 miles. At first we went to Iowa City, because it was the shortest route to a railroad. When a new section was opened on the Dubuque line, we changed to that, until the Rock Island line was extended so as to make the least hauling that way. So in the course of years we changed from one route to the other several times. A fair sample of travel in those days can be best shown by recounting my first trip to a Republican state convention. It was in the summer of 1858, and the convention was held in Iowa City. To-day we could go by three or four different railroad routes, reaching the old capital in a few hours. But at that time the only way I could get down there to cast the vote of this county and several more up north, for which I held proxies, was to take 
the stage to Dyersville, thence by rail to Dubuque. At that point I took a steamboat for Davenport. From there I went to Iowa City by the Rock Island Railroad. This made upwards of 400 miles, saying nothing of the bottomless sloughs on the wide prairies. We left Webster City in a lumber wagon drawn by four horses, to which the stage company always resorted in a muddy time, stopping over night at Iowa Falls, Cedar Falls, and one other point before reaching this end of the railroad. The trip out was pleasant enough, but returning was a different thing. Rains had descended, the creeks were all high, and the sloughs full of water. The little Beaver Creek which empties into the Cedar near Cedar Falls was half a mile wide, and in many places looked like a great lake. The roads were badly cut up, and we had several times to get out in deep sloughs and help the driver in extricating the wagon or coach. Three or four miles east of Iowa Falls, and just as darkness was descending upon us, the old, lumbering coach stuck fast, the wheels settling into the soft ooze to the hubs. There were five passengers - a stout lady, her husband, and a friend, and V. A. Ballou, a printer boy whom I had picked up in Dubuque, and myself. Ballou and I waded out, while the two other gentlemen, who were taller and stronger, brought the stout lady ashore witil wet feet and other annoying disarrangements of her toilet. There was no way to reach Iowa Falls except to "foot it," and we all struck out at once. Darkness was rapidly coming on, and vivid lightning, loud thunder and black rolling clouds, made things look very portentous to the west of us. The rain held off until we were within a mile of town, when it came down upon us in torrents, drenching us to the skin. We could only see the road by the flashes of lightning which followed each other in rapid succession. The brave lady and her husband, like "the hardy pioneers" they were, reached town half an hour later. It being a work of time to release the coach from the deep, stiff mud, our journey home was in the customary lumber wagon.

People who have only seen our country during the past ten or fifteen years can scarcely imagine the indescribable beauty of the prairies before they were settled. Grass, both on the uplands and in the sloughs, grew rank and luxuriant as it is never seen in these days. I remember driving across a Des Moines River bottom a 
mile wide, some thirty miles north of Fort Dodge, in the summer of 1858 . The most of the way across the grass was higher than the top of the buggy. And so it was in thousands of places. Then what myriads of prairie flowers we had in those days! They began to come in early spring and they kept coming all the season through until the frosts of autumn destroyed the last and most beautiful of all, the aster, and the golden rod. The prevailing colors were white, purple, and yellow, though some of the phloxes presented different tints of red. But now a single acre of prairie, as it was seen in those days of primeval luxuriance, is seldom found. The breaking plow and the heavy pasturage have obliterated both the luxuriant grasses and the beautiful flowers, and like the Indians and the animals which roamed over this region forty years ago, they have passed away and they will never return.

One of the most interesting features of the old times in our county was the regularly recurring autumnal prairie fires. Not more than twenty-four hours after the first hard, killing frost, great masses of smoke would be seen rising in almost every direction, while at night the sky would be lit up by the flames. True, the law was very severe upon any person convicted of setting out a fire, but then no one seemed to regard it or try to enforce it. And so the grass was burned off each season just as it was in the ancient times of Indian occupation. But gradually as settlements increased, the red lights in the evening skies became fewer, and now they are seldom if ever seen.

Our elections, sparsely as the county was settled, were always exciting. They were preceded by vigilant, energetic work, and when election day came each party sent out from town some of its best men to attend each voting place throughout the county. I remember a little incident of the campaign of 1859. Two men, one on each side, spoke at the school house at Lakin's Grove. One claimed that his party were the genuine pioneers of the county, calling the other side a set of kid-gloved gentlemen. He would have said "dudes," only that expressive word had not been invented. "Why, ladies and gentlemen," said he, "when I came into this county, I lived on small potatoes-yes, small potatoes and salt!" And suiting the action to the word he measured off the end of his little finger saying, "Small potatoes, not bigger than that!" When his eloquent opponent took the floor in reply, 
he said he would admit the small potato story to be true. The great trouble with his friend was that "he had eaten too many of those small potatoes!"

During the five years in which I published the Freeman I never saw any dull days. There was always plenty to do, and tasks so multiplied that occasionally a week went by in which no paper was issued. Local news seemed to be abundant, but we only had one mail a day, and railroads were still indefinite institutions of "the good time coming." I started out with the idea of having a local department in the little paper, separate and distinct from the news and politics. But the second week when I came to make up the "forms" all the reading matter was local except less than a column. I therefore abandoned the attempt to have a separate local department, and the locals went in with the other matter as came most convenient in the general arrangement. Many of the farmers made it a rule to come to the printing office every time they were in town, and from them I always obtained the news transpiring in their neighborhoods. It was a free reading room for all.

I published the Freeman until September, 1862, when I locked the office and went into the army. Vivaldo A. Ballou went out from the office first, in 1861, but came home a year or more afterwards, completely wrecked in health. He was in the memorable cavalry charge at Farmington, where he gave up his horse to Colonel Hatch, whose horse had been shot down. Ballou crawled out through the bushes, and thus made his escape. James Faught, our pioneer county surveyor, was in the same wild charge and was severely wounded. George H. Welsh, a boy who had learned his trade with me, now of Boone, was also a soldier in Company A of our regiment-the old Thirty-second. He served till the close of the war, participating in many of the severest battles. While we were away the Freeman office was mainly in charge of Fred A. Bolt, a very small lad, who, after a fashion, could print election tickets or small hand bills. Ballou revived the paper in 1864, during my absence, and I afterwards sold the office to him.

I wish to say a word about poor Tom Drummond. He was from Virginia and said to be a descendant of Pocahontas. $\mathrm{He}$ was slim and tall, his flashing eyes and flowing hair as black as 
jet, and he was really very handsome. He lived for a time at Mason City, but was long the editor of the Vinton Eagle, which he made one of the brightest papers in the state. He was a leading spirit in founding the Blind Asylum at Vinton, and served in both branches of the state legislature. While a senator, Governor Grimes got him an appointment as second lieutenant in the Seventh United States Cavalry. He rose to a captaincy, ranking Custer at one time. He went safely through the war, but in the last fight, at Five Forks, after the firing had ceased, he was mortally wounded by a chance shot and died that night. Our state never contained a more gallant spirit.

Ladies and gentlemen, I have come to the end of my chapter, though there are many things I would still like to say. I wanted to say some kind words of many of the old editors of Iowa who have either gone to their final rest, retired from the profession, or engaged in other fields of usefulness. Some have died at their posts, in the midst of their labors, some "foremost, fighting, fell" on southern battlefields, while a very few "still live." It was my fortune to know many of them intimately and well, and others I knew almost as well through the courtesies of the exchange list. But the time is too short. My story began with northwestern Iowa as a wide, unsettled waste, covered deep with the snows of one of the severest winters ever known in the West, and with but a poor settler here and there along the streams. Even in summer its timberless prairies were so wide that well-informed people seriously doubted whether they would be settled for many generations, if ever. There were plenty of good people in Webster City and Fort Dodge who really thought they had come very near to the "jumping-off-place." But its close finds this great region threaded with railroads and converted into a veritable garden. It is dotted with flourishing towns and villages, and in traveling over its broad expanses one never sees a saloon or finds himself out of sight of a schoolhouse. Its rural population is prosperous beyond any other in the Union, for every autumn sees the barns literally bursting with plenty. While all classes of people have done their part toward the rapid development of our most abundant natural resources, I believe that the public journals at the various county seats deserve a high meed of praise for their constant efforts to advance the interests of the regions 
round about them. I know that every country editor does a thousand things every year to promote both individual and the public welfare, for which there is no other reward than that which arises from the consciousness of having done well whatever his hands have found to do. And so they will continue to act, in guarding with untiring vigilance the best interests of the intelligent and enterprising people among whom their lot is cast.

\section{ANOTHER REVOLUTIONARY VETERAN GONE}

DIED, in the city of Wilmington, on the 29th ult., Captain David Kirkpatrick, in the eighty-seventh year of his age. He was the last surviving commissioned officer of the Delaware Line.

Never was old age more beautifully portrayed than in the deceased; the gentleness of manners, the benign expression of his eye, the quiet tones of his voice, rendered him an object of deep interest, and never was filial piety more lovely than was exhibited in the comforts which surrounded this aged veteran. The tender hands of affectionate children had long "Rocked the cradle of declining age," and the blessing of God will rest on his posterity, "because they did rise up before the hoary head of their father and honored him in his old age."-Missouri Republican, St. Louis, June 15, 1839. (In the newspaper collection of the Historical Department of Iowa.) 
Copyright of Annals of Iowa is the property of State of Iowa, by \& through the State Historical Society of Iowa and its content may not be copied or emailed to multiple sites or posted to a listserv without the copyright holder's express written permission. However, users may print, download, or email articles for individual use. 